\title{
Elixirs and Fabulous Potions: On Critical Theory in the Philippines Part III (A Philosophical Fiction)
}

\section{F. P. A. Demeterio}

$\mathrm{F}$ aith Contreras-Fernandez, a much admired assistant professor of industrial chemistry in the same university where Fred Gonzales was enrolled and where Peter Mirano was teaching, was rushing from her laboratory towards the small function room adjoining their cafeteria. There, a bull session comprising of union leaders from her own university, as well as from the other schools of the university belt, was going on.

These militant workers were exploring the implications of the recent move of some powerful taipans of buying their way into the board rooms of a number of educational centers in the metropolis. The Filipinos' legendary demand for higher education and the country's robustly growing population added up into an expanding business opportunity that lured these enterprising Filipino-Chinese magnates into investing some of their capitals in the universities, either clandestinely or under the guise of philanthropic advocacy for the betterment of Philippine education. But these union leaders who were closely following that trend were anticipating its chilling aftermath in the form of a brazen and crass commercialization of Philippine education. They were expecting that these taipans would heavily invest on the more tangible buildings and facilities to attract more enrollees, but would secretly clamp on the less tangible capital expenditures such as employee salaries, human resources development, library books and faculty research. In no time, these taipancontrolled universities would be run like their giant malls that appeared externally sleek, neat and flashy, but were actually festering internally with the sufferings of their armies of minimum-wage-earners who were engaged only on a five-month contractual basis.

Faith's highly politicized and ideological dedication to science education had been forged two decades earlier in her class on science, technology and society in that rather elitist Catholic university along España Street. Her professor, a huge cleric who himself was a chemist and who belonged to the same religious group who owned their university, delivered what for her became an unforgettable lecture. Fr. Roberto Castillon was talking about archaic models of science when he compared the European alchemist and the Filipino babailan. In her mind, she could still hear his thundering voice when he stressed: "You know, class, alchemy, with its 
obsession for wealth and everlasting youth, is an earthly, materialistic, sexual and individualistic endeavor; the lore of the babailan, on the other hand, with its emphasis on healing, communal safety and bounty, is a spiritual, relational, and collectivist endeavor. If the alchemist is motivated by personal greed to alter nature, the babailan is moved by a sense of social duty to re-establish the harmony and order of nature."

"Come to think of it, modern chemistry did not only kill alchemy but also scorns its memory as an unfortunate segment of its own ancestry. Modern chemists would think that alchemy had been a misguided and superstitious venture. But that is exactly the tricky part, because in a deeper analysis, chemistry actually inherited much of alchemy's materialism, greed and individualism, giving it a concealed force that is both sinister and destructive to both nature and society." Then her professor opened her and her classmates' eyes to the possibility of enriching Philippine chemistry with the spirituality, and the sense of social duty to re-establish order and harmony that are both nestled within the archaic model of the babailan. "Dapat ang kemikong Pilipino ay tatahak sa dakilang landas ng mga babailan; at unti-unti nilang itakwil ang materialismo, kasakiman, at pagka-makasarili, mga katangian na namana ng chemistry mula sa alchemy. Should this happen, the Filipino chemist would cease to blindly serve the interest of multinational corporations, but instead attend to priorities of Philippine society, such as food production, research for affordable medicine, exploration for renewable sources of energy, and the conservation and protection of the environment."

To stress his point, Fr. Castillon strode towards the window, pointed to the rooftop of their Renaissance style building where granite statues of some twelve giants of western humanism were perched: the theologians Vincent de Beauvais, Augustine of Hippo, and Raymond de Peñafort ; the philosophers, Aristotle, Albert of Cologne, and Plato; the tragic writers Calderon de la Barca, Sophocles, and William Shakespeare; and the comic writers Lope de Vega, Aristophanes, and Moliere. He declared to the class: "T'yak na bindi n'yo alam $n a$ at least three of these colossal university icons are European alchemists, and it is unfortunate that our chemistry department exists under their shadows. Maybe the time has come for our university to consider replacing these intellectual figures with local ones to be able to send to all our students and alumni a more politically appropriate signal that an unreflected aping at the western models will not propel this nation forward."

Faith understood the point of her professor clearly, but she shuddered at his proposal of actually tearing down these sculptures that have already become part of the cityscape. For her the three alchemists could stay, anyway most of the professors and students of her university were not even aware that the twelve granite figures at the top of their main building were supposed to have their own specific names and identities. "Akala ng marami mga paring Dominikano lang ang mga 'yan, o "di kaya mga decorative figures lang." In any manner, the ideology that the Filipino chemist must follow the spirituality and social orientation of the babailan was etched emphatically in her heart. 
As Faith expected, the small function room was only filled sparsely by the labor leaders. Eto na naman kami, pa-isa-isang magigiting na unionista! I know rather well how Filipino academicians, like the rest of the country's professionals, are uncomfortable with the idea of placing their necks in a labor group. They are thinking that this is not only a dangerous spot but something that is suitable only for the lowly factory workers and their left-leaning agitators. With their aristocratic mind frame, they find it selfdemeaning to stand out for their rights, to demand for fairer economic and political benefits, and to participate in pickets when necessary. At kung sino sino pa 'yung ayaw sumali, sila pa 'yung madalas nagrereklamo sa mababang suweldo ng mga guro! A business management professor from a small university belt establishment voiced out his cynicism that was perhaps born out of weariness and frustrations: " $M g a$ kapatid, I think it could be possible that our group may just be overreacting to the taipans' academic invasion. We have to remember that tertiary education in the country is controlled by the private sector anyway. There is no certainty that these taipans would be worse than our traditional religious and other private owners. Malay natin, baka nga mas matino pa itong mga intsik na ito." $\mathrm{He}$ suggested that instead of gearing themselves for battle, they could take a less stressful wait-and-see stance.

Peter Mirano, Faith's colleague from the department of languages and humanities, interjected. "Pero mga kasama, in my humble opinion, our good brother's call to give these taipans the benefit of the doubt is a little bit unreasonable. We all know very well how these moguls are obsessively motivated by profit making, how they circumvent laws to minimize the payment of wages and benefits to their workers and prevent unionism, how they are in the position of giving hefty financial contributions to presidential candidates, and even of fielding their own puppets in the congress. Mabirap magbakasakali sa ganitong sitwasyon." Peter pointed out that there was no way for anybody to stop their influx, but the educational labor unions could find some means of resisting the further commercialization of Philippine education.

Faith could anticipate her friend's flow of thinking. She stood up and presented to the group the necessity for their labor unions to federalize, and link up with student organizations. With a wider network they could address the dangers and threats of the taipans' creeping presence easier. "If we, the educational workers, together with our students, can put up a monolithic frontline, we will not only foil these Filipino-Chinese magnates' profiteering desire, but also convince them to dedicate their legendary business management skills for the development of Philippine tertiary education. We should not exclude the possibility that something good might actually come out from this looming threat. As the Filipino-Chinese themselves would say, the Chinese ideogram for crisis is actually the same as that of opportunity." The militant educators and labor leaders, including the business management professor, nodded their heads in affirmation of Peter and Faith's ideas.

Even as a college student, Faith was already different from her classmates. In their university, their college of sciences shared their graniteclad main building with the central library, the college of law, the museum, and the central administrative offices, during the day; and with some specters of 
Spanish friars, Japanese soldiers, Filipino guerillas, and the former university registrar, during the night. Inside its Renaissance-inspired prewar architecture was a labyrinth of offices, courtyards, stairways, classrooms, mezzanines and laboratories, and it was here where the rest of her classmates spent most of their four-year stint for their bachelor's degree in chemistry. Faith, on the other hand, ventured outside its massive walls and into the campus' idyllic gardens, fountains and gazebos, where student leaders from the other colleges regularly converged. Although that intense involvement with student politics had been identified by those close to her as the cause why she was 0.05 points short from bagging the much coveted rector's award for academic excellence in her college, she never regretted it, for aside from the fact that it was there where she formed a more realistic outlook in life, it was also there that she came to meet Arnold Fernandez, the president of the student council of the college of engineering at that time.

Arnold had been a true representative of the rather raucous crowd of engineering students that thrived at the south-eastern corner of their twentytwo-hectare campus. His leadership and activism had been made precarious by his frequent night outs with his friends, more frequent practices and gigs with his band where he played the bass guitar, experimentations with alcohol and drugs, and, of course, his plummeting grades. To the dismay of his jealous clique, Arnold started to change his lifestyle as he spent more and more time with Faith. The fair skinned, petite, curly haired and vivacious chemistry student was overwhelmed by the attention showered on her by this dark, long haired and a little rugged-looking hunk, and finally agreed to go steady with him. It took him weeks to regain his leadership and popularity in his college with his much acclaimed series of forums on socio-political awareness that was capped by a fund raising project for the benefit of a small scavenging community living beside the metropolitan garbage dump-site. But it took him months to appease his musical group with his continuous flow of Tagalog rock compositions. He finally learned to pin down his demons and dedicate his passions to Faith, his studies, campus politics and his musical writing that all manifested in the flames of his creative impulse. From a reckless leader and bohemian artist, he was transformed by Faith's company and attention into a more self-restrained and disciplined student politician and musician.

Like any other young lovers, Arnold and Faith spent much of their time together talking about what is in store for them in the future. But with their keen visions they found it difficult to separate their dreams as lovers from their dreams as Filipino science students. What Faith liked most about Arnold was his sharp and circumspective mind that made him stand out from the rest of the science students who were all deeply mired in the narrow pits of their specializations and who were never bothered by the thought that they were actually condemned from the very start to become minions of the huge multinational manufacturing corporations. Although in the conservative premises of their Spanish frailocratic campus, Marxism and post-colonial critical thoughts were not seriously and systematically discussed, Arnold was able to articulate clearly that the problems that maligned Philippine science were 
intricately tied to the problems of the country's history, economics and politics. Neither of them could reckon the number of hours they had spent, and the golden brown thin crusts and mugs of beer they had consumed at that American pizza chain in front of their university while pondering on the ailments and prospects of Philippine science.

There were many professors in their university who stressed that Filipinos should put an end to the practice of blaming the Spaniards and the Americans of the past for each and every misfortune experienced in the present. Maybe such an ideological trend had something to do with the actual presence of the remaining Spanish clerics in their campus. Mostly old, small, hairy, and flushed with the metropolitan heat, they could be seen prancing about the football field for their late afternoon paseo. Yet, Arnold was insistent that both the Spanish and American colonization had left behind unfavorable structures that were still operational at that time.

"You know, Faith, sweetie? I am becoming more and more convinced that the wretched status of science in our country is just an effect of one particular structure that was formed by our four hundred years of political and economic oppression. Hindi tayo dapat maniniwala sa kasabihan na ang nakaraan ay nakaraan na at dapat nang ibaon sa limot. Alalahanin natin palagi na ang nakaraan ay s'ya ring nagbubog sa kasalukoyan."

"What exactly is that particular structure that you are wary about?"

"I am referring to our economic system that the colonizers had constructed to be a fusion of feudal exportation of raw materials and comprador importation of manufactured goods. Isipin mo nga, Faith, ito yong kabaligtaran $n g$ ekonomiya ng mga ma-uunlad na bansa kung saan raw materials yong ini-import at manufactured goods 'yong ini-export."

"At ano naman kung ganoon nga, ha, Arnold?"

"Ay naku! Malalim ang implikasyon ng ganitong baligtad na sistema ng pangangalakal. Look, the imbalance between the cheap and low technologically produced raw materials on one hand, and the expensive and high technologically produced consumer goods on the other hand, would not only create widespread poverty but also prevent the development of science and technology in the country. Parang dalawang beses tayong pinatay ng sarili nating ekonomiya. Isipin mo nga, Faith, on one side, the absentee feudal landlord does not really care about science and technology for he can gather his harvest using traditional methods and export them as raw materials. On the other side, those multinational and foreign corporations use first world science and technology to fabricate their products. Hence, between the economies of feudal exportation and comprador importation, Philippine science has no place to grow.”

Faith saw the clarity of his diagnosis and expressed her view of how futile the government's expenditure for special science schools was if the dysfunctional tandem of feudal exportation and comprador importation remained in place. "Palagay ko, it won't matter how many thousands of brilliant students from the public science high schools and technological universities are graduating each year, as long as the Philippine economic system does not have 
a career waiting for them, our science and technology will remain underdeveloped. Nag-aaksaya lang pala tayo ng pera."

"Tama ka, Faith. At ang masaklap pa, dabil nga sa kawalan ng opportunity dito, yon nagsisipuntahan sa abroad ang mga graduates nila." They laughed at the government's desperate tactic of propagating the myth of Agapito Flores, the alleged Filipino inventor of the fluorescent lamp, that was complete with a ridiculous etymology banked on the phonetic resemblance between the name Flores and the adjective fluorescent. They understood perfectly that the agenda was to make Agapito a role model to encourage young Filipinos to pursue careers in science in technology without even thinking that the fluorescent lamp was a product of more than seventy years of research and development in Europe and America, and could not have been produced overnight by a simple electrician from Guiguinto, Bulacan, in a makeshift kitchen or garage laboratory. "Hindi masamang magbigay ng inspirasyon sa kabataang Pilipino. Pero bindi naman yata tama 'yong pambibilog nila sa ulo natin?' She commented.

It was not that they had totally lost their hope on Filipino ingenuity. Rather, they believed that ingenuity was just a raw force which cannot be harnessed without the economic opportunities, research funding, laboratories, and other support programs. Faith speculated: "The only way to break the vicious cycle of poor science education, miserable condition of science and technology, dependence on imported products, widespread poverty, and back to poor science education again, is to drum it into the heads of the lawmakers that the time has come to legislate laws that would restructure the country's economic system away from the dysfunctional fusion of feudal exportation and comprador importation. 'Di ba, Arnold?"

But the thought that everything depended on the country's solons painted shades of despair on the lovers' faces. They simply could not imagine how the bunch of crocodilian people in the congressional hall, who were too preoccupied in gobbling up their pork barrel funds and throwing the crumbs and morsels to their equally reptilian constituents, could ever think of goading the country towards the complex pathway of development. "Pag si congressman na ang kasali sa usapan, lumalabo lalo ang patutunguhan natin d'yan!" Arnold stressed. No matter how crisp their analyses were, they were merely two young science students dreaming about their future in an American pizza chain.

Three years later, as the economy of feudal exportation continued to diversify into labor and human resources exportation, Arnold distressfully found his own self transmogrifying into a cheap raw material. "Hindi na abaca, bindi na asukal, bindi na niyog ang pangunabin nating produkto ngayon, Faith. Katawan na natin ang ibinibenta natin sa ibang bansa." Sooner he was working in an American oil company based in Saudi Arabia. In the desert landscape, not even the government crafted tagline of bagong bayani could console the desolation of his spirit.

The following year, Faith grabbed a scholarship that was hoisted by the British cultural center in Manila to attract promising young Filipinos, and pursued her higher studies in industrial chemistry in London. She suffered the loneliness, cold, discrimination and the overall feeling of being dislocated, for 
the belief that that was her only chance to experience world class education, thinking that not even the resources and facilities of the prime state university could match what she was having on that side of the globe. Although cruel distance separated them from each other, the lovers remained true to the promises they made some years earlier one early evening underneath a fire tree bough in their tranquil university garden.

Faith thought that her involvement with politics was just a phase in her student life that she would eventually outgrow. But she was wrong, a decade after she returned from her graduate studies, she was still in the maelstrom of an even more complicated and dangerous politics. The cold misty weather and the sweet English life only fanned the raging flames in her heart. Her first hand experience of what science and science education were like in Cambridge gave her a point of comparison to sharply see the poverty of their Philippine counterparts, just as her eyewitness' perspective of the mature Londoner labor unions, ever proud of their ancestry that can be traced back to Karl Marx himself who lived and died as an exile in their city, gave her a similar point of comparison to unmistakably see how disarrayed the Philippine workers were. Thus, back in the country, instead of accepting the job offers from some big corporations or the teaching invitations from the elite metropolitan universities, Faith opted to work in a modest university to carry out a mission of concocting a life and career through blending education, advocacy for the development of Philippine science, and labor politics together with the less fortunate denizens of the microcosm on Recto Street.

Faith frowned at the cafeteria manager as she supervised two of her staff members in serving the Styrofoam lunch boxes to the already famished militant labor leaders. Her comrades heartily munched through their bland and greasy fare, too hungry and too naive to care about the impact of their food containers on the ozone layer and on the global climate. If only they were in a more appropriate situation, she would most probably deliver them a scathing homily on environmental ethics. But all of them were pleased with their scheme on how to jumpstart a federation of labor unions in the university belt and then work on a wider metropolitan linkage. After merely picking on the green vegetables and white chicken meat, Faith whispered to their union president: "Kapatid, I have to go ahead. There is a senior student who has an appointment with me. I think we have accomplished something great today. Maraming salamat sa iyong liderato at mabubay ang manggagawang Pilipino!"

She was actually expecting Fred Gonzales, a chemical engineering student whose research on coconut bio-diesel she was mentoring. She knew him since the time he enrolled in her chemistry 101 subject. Brilliant, hardworking, silent, yet articulate, and a natural born leader, it was very difficult to miss Fred among the sea of students that flowed in and out of her classrooms and laboratory. She developed a close friendship with him because he too was a favorite student of Peter. The three of them had become habitués of the tea houses along Ongpin Street. Often, they were joined by Fred's lovely girlfriend, Juliana Sandoval, and dormitory buddy, Charles Mendoza, a philosophy student from an elitist school at the southern tip of Recto Street. 
She found it very edifying to interact with these folks for they seemed to connect her to those days when she too was a young and spirited radical student.

Faith's laboratory, which she shared with three other professors of applied chemistry, was located on the third floor of the north wing of their science building. Its interior was dominated by ten long tables with battered sinks and rusty water spigots, and surrounded by un-repainted closets carrying thick ancient glassware and an arsenal of probably expired reagents in amber colored bottles and jars. The acrid smell of some stashed compounds thickly permeated its poorly ventilated interior. With just an addition of a fireplace, a cauldron, and a wood and leather bellow, the room could already pass as a filmic or theatrical set of an Arthurian wizard's den. It was obvious that only the very basic textbook experiments can be done there, and Faith had to use the laboratories of her more fortunate college classmates who happened to work in well-funded universities or in big chemical manufacturing companies and who were kind enough to smuggle her in during off hours.

Five minutes before their appointed time, she already saw Fred through the cracked porthole glass of the laboratory door, excitedly holding what looked like a copy of the day's newspaper. Faith was amused by his obsessive dedication for excellence, for his undergraduate research paper, and for Juliana. She found his behavior and punctuality very similar to her European classmates at Cambridge, Hippolyte Labrunie from Poitiers, Elizabeth Hastings from Birmingham, Wilhelm Schumacher from Strasburg, Hans Koenigpoel from Amsterdam and many others whose names she can no longer pronounce. Like clockwork, she could tell that right at that moment Fred must have come straight from the hospital where his girlfriend was having her OJT. He was designing a system that would make bio-diesel production a cottage industry, where the coconut farmers themselves would be the ones to extract this new fuel in smaller batches and bring them to a central barangay depot for purity testing and storage, and where the town fuel stations would do their collection, mixing with petroleum diesel, and subsequent retail distribution. Fred's revolutionary intention was to allow the small farmers to benefit directly from this new industry without the intrusion of too many, and often rapacious, middlemen.

Fred's interest in bio-diesel germinated from one of Faith's classroom anecdote of an American environmental activist who insisted of running his car on bio-diesel that he produced in his garage from waste vegetable oil. Part of his weekly routine was to go around his small town's restaurants collecting their used deep frying oil. With basic chemistry and kitchen tools he extracted clean bio-diesel from the waste stuff. Faith wrapped up the anecdote with an unforgettable punch line. "Ladies and gentlemen, please take note that the setting is America. I honestly doubt if the same story can happen in our country. In the Philippines, waste cooking oil is one of the many things that can't just be collected for free. Syempre, kakaiba tayo, five star restaurants sell their used vegetable oils to smaller and less prestigious establishments, who in turn sell them after using to still smaller and less prestigious establishments, 
who in turn sell them to poorer households where they are used as grease to fry the smelly dried fish or to sauté various dishes, until they end up in the human body or in the sewers." Faith declared to the chuckling students: "There is no such thing as waste vegetable oil in the country." But Fred was intrigued with the concept, and as he read the local literature about bio-diesel he stumbled on the inconspicuously ongoing research of the Philippine Coconut Authority about the industrial production of $\mathrm{CME}$, or the coconut methyl ester.

Upon entering Faith's laboratory, he immediately spread the broadsheet that he was carrying on the instructor's desk: "Good afternoon Ms. Faith! I have with me good news and bad news not only for the two of us but for the whole country as well. Ano po'ng gusto nyo'ng uunabin ko?"

"Hello, Freddie! Of course, I would like to hear the good news first. That paper is certainly brimming with bad ones. So, shoot, I'm listening!" Fred opened the newspaper to the second page and pointed at an article entitled Bill on Bio-Fuel Finally Signed into Law. "Ma'am, the good thing is that after some years of waiting, the Philippine legislators had finally approved the bill that would require all pump stations to blend their petroleum diesel with coconut bio-diesel. Imagine? After more than a decade of lagging behind the other countries that started to utilize and mass produce bio-diesel in the 1990s, we finally have a law that would hopefully arrest our growing dependence on Arabian oil. 'Di po ba napaka-meaningful to para sa aking ongoing research?"

"That is very nice to hear, Freddie: a major victory for our coconut farmers and environment, I may say! But what is the glitch that came with the new law? Ano 'yung bad news na nabanggit mo?"

"Well, the bad thing is that the law is very conservative in stipulating for the mandatory blend of only up to five percent, when researches here and abroad have already established the safety and efficiency of a ten to twenty percent mixture with petroleum diesel. Noong nabasa ko po 'to kanina, talagang napamura po ako sa sobrang asar."

"What! Five percent is definitely a joke! Are these so called lawmakers even aware that car manufacturers in Europe are now scrambling to proclaim that their latest model, so and so, can run of even more than thirty percent blend, and that they are racing to create the ultimate model that can run on a hundred percent pure bio-diesel? Palagay ko dalawang bagay lang ang p'wedeng magpapaliwanag d'yan. It is either talagang mga ignorante itong mga mambabatas natin, o di kaya ay nasubolan lang sila ng mga petroleum companies."

"Well, Miss Faith, I'm more inclined to think that the shortcomings of our local version of a bio-diesel law are just a proof how slow and ill-informed the kind of people that we are putting in our legislative halls."

"Yeah, I could not disagree with you. We should not expect too much from a bunch of people whose legislative expertise has narrowed down to the naming and renaming of streets and public schools. Tama ka, Fred, ang sarap talagang magmura. Bloody hell! Holy arse!"

"Wow, ang taray po palang pakinggan ang mura ng mga taga Cambridge!" 
But no matter how late and how conservative the new law was, for Fred coconut bio-diesel held so much hope for the ailing Philippine economy. Coconut is among the highest yielding oil producing crops, and its cultivation had already been mastered ages ago by the Filipino farmers. The CME, which is the coconut bio-diesel itself, although a little more expensive than the current prices of petroleum diesel, is more energy efficient in terms of mileage, and has less particle emission, making it an economically and environmentally sounder fuel alternative. As an added benefit, the coconut bio-diesel, due to its being a better solvent, could actually clean the engine while running, and its carbon exhaust would be reabsorbed into the photosynthetic carbon cycle of the growing coconut trees. If congress would amend the mandatory blend to ten percent, this would translate into a little more than ten percent reduction of the country's diesel oil importation, equivalent to billions of pesos in savings, and an incalculable windfall for the local coconut industry.

Faith was amazed by the intricate details of Fred's proposed system of pulling coconut bio-diesel production down to the scale of a cottage industry. In his paper, four or six farmers could put up his designed mill, press, stove, mixing bins, diesel/residue separation device, and storage tanks at affordable costs. These simple machineries could be readily constructed even by small machine shops and iron works stalls. The chemical reagents that would be used in breaking the long molecular chains of coconut oil into shorter molecular chains of coconut methyl ester, and in testing the purity of the finished product, would be packaged in calibrated kits that could be retailed in agricultural supplies store or distributed by the barangay centers. Faith smiled: "Just think of it, Freddie. How ironic it can be to see some coconut farmers transporting their newly extracted bio-diesel to their barangay depots using carabao sleds. That would be a perfect metaphor of the fact that latemodernity and pre-modernity are actually intertwined in this country!" But Fred was quick to qualify. "Ma'am, such imagery would only be a momentary arrangement. Once the system kicks off, in no time, these farmers will be using motorcycles or jeeps. I long to see these farmers transporting their biodiesel on tankers that are powered by their own CME extracts. Sana po mangyari ito bago pa man tayo pumanaw sa ibang mundo." rin pala!"

"Hanga ako sa yo, Fred. Hindi ka lang pala matalino, may pagkamakata ka

His review of related literature thoroughly examined the annual productivity edge of coconut per hectare of land over the other alternatives such as soybean, rape seed, or jatropha; tackled the history of the country's coconut industry; and looked into how international economists had estimated the annual increases of crude oil prices based solely on the fact its underground supply would most probably not last for another century more.

Fred insisted that with the simplicity of coconut bio-diesel production, there is no reason why its knowledge should be kept a secret from the farmers. "Ma'am, in the island where I come from, there is a legend that tells us that the first Visayans came out of two coconuts. I think it is so beautiful to imagine that after so many centuries of oppressions and sufferings, we as a people 
might find our salvation in the very same fruit where we locate our mythical point of origin. For our country, the coconut may not only be the tree of life, but the tree of our destiny as well."

While Fred's eyes were gleaming with enthusiasm and passion, Faith doused him with a little of her British-bred skepticism. "Keep your cool, young man. Napakamadrama mo! You have to realize as well that coconut biodiesel would never be the panacea of all the ailments of our national social economy. Hindi ito ang ultimate solution sa lahat ng problema natin."

"Huh, paano n'yo po nasasabi 'yan?"

"Alam mo, Fred, even if our congress would immediately amend the coconut bio-diesel law and stipulate a ten to twenty percent blend, or even a thirty percent blend, a huge capital expenditure still had to be laid out for farm to town roads, and tremendous amount of political will had to be exerted to resist the temptation of importing cheaper algae bio-diesel from the industrialized countries. Hindi ganoon kadali o kasimple, Freddie."

She pointed out. "Kabit na if our country can surpass these initial challenges, there are still a lot more waiting just around the corner. With the immense local demand for coconut bio-diesel, rice lands, sugar fields, vegetable gardens, pastures, and orchards might be converted into coconut plantations. As more and more of the limited agricultural tracts will be devoted to coconut farming, the prices of grain, vegetables, fruits, poultry and meat will certainly skyrocket. Anong magiging saysay ng sangkatutak na CME kung si Juan dela Cru₹ ay bindi na makakabili ng bigas at ulam?" Faith looked through the laboratory window and sighed that as the local demand for coconut bio-diesel would grow further farmers would be seduced to clear the virgin forests in favor of the oil producing crop and that would mean an ecological disaster was about to come. "Kinikilabutan tuloy ako. Yes, coconut bio-diesel could be a promise for all of us. But we all need to manage it well. Hindi ako uma-asa na basta na lang gagaan ang birap na nararanasan ng ordinaryong Pilipino."

The lady professor invited her student to think further what could be some of the implications of the coconut industry's sudden boom in the field of Philippine politics. "Pag-iisipan nga natin 'to ng mas malalim. The flow of wealth from coconut oil will not automatically make each and every Filipino richer, just as the wealth from petroleum oil did not make each and every Arab richer. The taste of oil money would definitely make the absentee landlords greedier and put up a more formidable resistance against land reform. Kung sakim sila ngayon, lalo pa silang maging sakim. Thus, instead of evolving into a society where small farmers will be tilling their own lands, our unfortunate country could easily retrogress into its feudal past where land will be controlled tightly again by some few elite families. You know it Freddie, as Peter Mirano would always say, when wealth is concentrated on the hands of the few, mapa-may-ari ng lupa man sila, mapa-industrayalista man sila, mapa-kapitalista man sila, o mapa-feudal coconut oil sheik man sila, the supposedly maturing Philippine democracy can also retrogress to dismal patronage politics. Kung baga ang bansa natin ay parang taong tumatanda ng paurong!" 
It is at this point where Faith revealed to her student the futility of Philippine science working independently from political activism. "Side by side with the establishment of a local coconut bio-diesel industry is the need for a more emphatic lobbying for real land reform. Without redistributing the feudal lands, the industry might boom, but it would not even alleviate the misery and wretchedness of the poor Filipinos."

"Naintindiban ko po ang ibig n'yong sabihin. Dapat pala talagang makikialam tayong lahat sa mundo ng pulitika, at tutokan ang problema sa lupa."

"Yeah, at hindi lang yan, Freddie, the political activism of the Filipino scientists should not even end with land reform, because granting that the hopeless congress could miraculously iron out a functional land reform program, there is still another danger that the new affluence might only be squandered for imported consumer goods, burying the country deeper into the mire of neo-colonialism. Alam mo? Madaling maakit ang mga kababayan natin sa imported products. Lalo na kung ang mga ito ay mura at abot-kaya. Just take a quick excursion to Divisoria and see how we are lapping up those cheap Chinese goods!"

"Nakakapangbina po pala ng loob kung makita natin ang lawak ng problemang binabarap ng bayan." But Fred understood the main point of his mentor that the Filipino scientist had to go out from the safe and controlled confines of his laboratory and engage with the socio-political complexities of the real world.

Despite its socio-political shortsightedness, Faith was extremely proud of her student's undergraduate research paper. "Huwag kang mag-aalala, Freddie. Brushing aside all those socio-political factors that we have just tackled, you really have a very good research work. I doubt it if I can see papers of similar quality among our graduate students."

"Ay, talaga po? Maraming salamat po, kung ganoon."

"Walang halong pambobola 'to. Talagang panatag ang loob ko sa trabaho mo. But we have to improve some of its parts." She suggested that he expand his recommendations section by proposing that Filipino chemists and scientists should focus not only on establishing a more energy efficient method of extracting the oil from coconuts, or finding some more profitable utilization of the desiccated coconut and grease by-products, or breeding higher yielding coconut varieties, but more so on looking for other kinds of oil producing crops and designing diesel engines that can run on twenty to one-hundred percent coconut bio-diesel. "Remember, young man, that the first diesel engine, created by the German engineer Rudolf Diesel himself, was actually designed to run on one-hundred percent peanut oil. So there is no reason why Filipino scientists cannot work out a machine that would totally subsist on coconut bio-diesel." Fred scribbled all her suggestions on a sheet of paper that his professor pulled out from her table drawer. He had a glimpse of what looked like a stack of corporate job offers from famous medical and manufacturing laboratories.

Faith checked her watch and apologetically told her student that it was already time for her to leave the campus to pick up her daughter at an exclusive high school for girls. "But, Freddie, we can actually continue our discussion 
while going to the parking area. If you would not mind, I can even give you a lift back to your dormitory?"

"Oh, that would be great! Madami pa po kasing akong gustong itanong sa inyo. May I carry some of your things, Ma'am?"

Basing on the elitist standards, her car may just be a modest Korean made vehicle, but she and Arnold made the tough decision of buying it four years earlier when their daughter, Millicent, entered high school and had to travel back and forth on a daily basis from their suburb home to the metropolis. Thus, while most of her colleagues' faces were darkened from the heat and sooth of too many jeepney rides, Faith found herself lucky to be driving her own small car. Without Arnold's sacrifices at the Arabian Desert, she doubted if she could have the luxury of devoting her career in that white collar sweatshop in that microcosm on Recto Street. She was afraid she would have succumbed a long time ago to the tantalizing offers she was receiving from both high end academic and corporate institutions. She realized that her idealist principles--that the youth in that part of the metropolis needed as much scientific training as the youth in the hallowed campuses of the expensive universities, and that it was a shame for them to be deprived of it for the sheer reason that they cannot pay higher tuition fees--could not be actualized without Arnold's stable financial backing. For that she felt a tinge of envy at the purity of Peter Mirano's dedication for educating these less fortunate denizens of Recto Street while subsisting solely on his meager assistant professor's paycheck.

In their university, just like in any other less prestigious academic institutions in the metropolis, professors and instructors were stretching their paychecks by taking teaching loads beyond their twenty-four hours per week regular assignment. Some very enterprising ones would carry up to thirty-six or forty teaching hours each week, sometimes spread over two or three different universities. In the United States, teachers like these were called gypsies, but in the metropolis, they were simply known as lagaristas. But the work and stress from such a staggering burden would not only translate into additional wrinkles on their brow, but burn out their teaching zeal and reduce them to spiritless automatons mechanically babbling out lessons from yellowed and darkened notes. More detrimentally, their time and energy for professional enrichment, research and publication were devoured by their extended classroom hours and trips from one university to the next. But with Arnold's remittances, Faith had easily resisted the temptation of taking an extra teaching load, and instead devoted her time and energy sharpening her modules, writing new teaching materials, and pursuing whatever inexpensive research projects that her own savings can finance.

Freed from tight monthly overhead expenses, Faith had the means to explore and experiment with the endless choices of inexpensive and even slightly expensive clothing and accessory items, which further honed her innate taste for style. Fashion is not very different from chemistry, where inexpensive articles are brought together to produce certain blends and contrasts that would project a seemingly expensive but definitely elegant and personalized 
statement. If the ultra-anti-colonial Peter Mirano did not allow imported shoes, jeans and jackets in his wardrobe, Faith had a more liberal attitude for foreign products. She never hesitated procuring them as long as they were heavily discounted on sale. The reason why she stood out among her female colleagues, who were financially forced to be contented with their perennially unfashionable apparel of subdued earth colors, was a combination of the facts that she had an eternally beautiful face, that she possessed an agelessly gorgeous body that could make the drabbest smock appear like a designer outfit, and that she was gifted with a cultivated eye for fashion. But as her younger, daring, but less innovative, colleagues pathetically copied her personal presentations, Faith was pressured to explore and experiment some more to be able to stay always a cut above her crowd.

But for all her privileges, Faith had to pay dearly by leading a profoundly difficult life of an OFW's wife. Many Filipinos roguishly think that the greatest sacrifice involved in my kind of life has something to do with sex, or the absence of it. But that is just so silly. Napakababaw naman ng pag-iisip nila! For a Filipina having to forego the carnal pleasures for a number of months in a row is notbing compared to the crushing feeling of being alone and away from that zone of comfort, safety and wholeness at the side of her husband. Faith still wept a river each time Arnold sends home a video recording of his latest love song that he performs with his acoustic guitar. There was that gnawing fear inside her heart that something wrong might happen to him in that vast and unfamiliar wasteland. With her crowd aware that she was an OFW's wife, she had to constantly fend off the nuisance pack of potential seducers who inaugurate their sinister moves with seemingly innocuous invitations: "Naglunch ka na ba, Miss Fernandez?" "Mag-starbucks naman tayo, Faith." "There is this very cozy vegetarian restaurant in Malate, Faith. Would you care to have dinner there with me?" But true to her name, she remained ever faithful to her one true love.

Although she had the money to spend, Faith had to constantly economize so that every time Arnold was on vacation he would be convinced that she was not squandering away his hard earned bucks. She had to learn in what schemes and in which banks should she invest his savings. Added to these hardships was the stress from appeasing her ever suspicious and jealous in-laws, Arnold's parents and siblings, with continuous love offerings.

Faith and Fred went on with their discussion about his research paper as they drove out from their university. After dropping him in front of his dormitory, she steered towards the Ayala Bridge and made a left turn to the direction of a convent school for girls that was established a century earlier by some German contemplative nuns. At the main gate she saw Millicent already waiting for her on a bench beside the guards' station. She was almost a perfect copy of what Faith looked like as a freshman chemistry student, lovely and exuberant. Except that Millicent got the darker skin tone and the impressive height of her father.

She was growing up so fast, in less than six months she would start her college education. Faith never regretted investing so much of her time taking care of their sweet daughter. 
"Hi mama, I just finished working on my math and science assignments. It is good that you arrive a little early."

"Well, it is always better to be early, sweetie. Do you need anything for any of your subjects tomorrow? We still have time to drop by that book and school supplies store."

"I don't think so, mama." Once inside their car, Millicent immediately picked a compact disc from her collection, musical genres that Arnold was also crazy about.

It might be easy to physically rear up their daughter alone, but the task of looking after her psychological growth was more than challenging. Faith had to compensate for the warmth of love, and the feelings of comfort, safety and wholeness that the physical presence of a father normally brought, and at the same time make their daughter understand that her father had to work in a faraway place just for them to have a decent life. She had to make him metaphysically present through her bedtime stories about him, about their past, and about the beautiful and romantic campus where they found each other.

During his vacations Arnold, both proud and jealous of the attention she was getting from the neighborhood teens, would play her round-the-clock bodyguard, probably unconsciously compensating as well for his absence for the rest of the year.

The rush hour was just about to emerge and Faith estimated that they can reach their suburban village in less than two hours. Had she made the mistake of tarrying fifteen minutes longer in her laboratory their car would surely get entangled for more than three hours in the turtle-paced flow of vehicles.

The house that Arnold built for them was a Mediterranean-inspired two-storey structure, with four bedrooms, three bathrooms, a carport and a small backyard garden. As they were spending most of their time in their respective schools and on the road, a Boholana housekeeper cleaned it for them and took care of their laundry twice a week. Their home was nothing grand, but compared to Peter Mirano's cramped quarters in that decaying accesoria it was already opulent and even ducal. Faith was aware that many of her colleagues were not fortunate enough to have a house of their own before hitting retirement age.

Arnold always talked about coming home, staying for good, helping her with her advocacy for science education by taking some teaching assignments on math or engineering, and maybe pursuing a higher degree in his field at the country's prime state university. "Alam mo, Faith? Gustong-gusto ko na talaga'ng dito na lang sa Pilipinas mamamalagi. Gusto kong balikan 'yong buhay natin dati na magkasama tayong mangarap at kumilos para sa bayan at sa sarili natin. Ito lang halos ang laman ng isip ko habang kumakayod doon sa napakalupit na desierto." But he always set his time frame in the near future: at the year when they would have paid the mortgage of their home, or a year after they would have settled the monthly installments for her car, or after Millicent would have finished college preferably in the same university where they both studied, or after they would have saved enough for a comfortable retirement. Faith hung on to these 
visions and dreams of that day when their family would be physically whole once again, when they could have their breakfast and dinner together day after day, when there would be no more crushing goodbyes at the Centennial Airport, and when she and Arnold would be pursuing their highly ideological advocacies hand in hand, very much like the time when they were still in college.

When they drove through the entrance of their village, Millicent was already asleep in her seat. Faith saw a quite unfamiliar sight in front of their home. Blocking their carport was a dark European luxury car. Her heart began to palpitate. Its two passengers, a stocky Caucasian wearing dark glasses and expensive barong Tagalog, and a Hispanic lady in a sleek business suit, were standing beside their vehicle, while their Filipino driver remained inside in his seat. The stocky Causian declared: "Megandeng gaabey pow! Good evening, Ma'am! We are looking for Mrs. Faith Fernandez, wife of Engr. Arnold Fernandez." Faith nervously rolled down her widow shield. "Good evening, sir, ma'am! I am Faith Fernandez." She pulled her car behind the foreigners' automobile, certain now that something had gone terribly wrong somewhere. The stocky Caucasian introduced himself: "I am Richard Cooper, ma'am, the manager of the Manila office of that American oil company where Engineer Fernandez is working, and with me is Miss Salve Gutierrez, our human resources officer. We have something very important to tell you. Could we come inside your home, ma'am?"

"Of course, Mr. Cooper and Ms. Gutierrez. This way please." Faith exerted great effort to keep her voice steady, but her knees already seemed like jelly.

Inside their neat and cozy home, with them seated on a couch beneath a Juan Luna reproduction, it was the turn of the Hispanic lady to break to the already terrified mother and daughter the bad news. "Please stay calm, but I have to tell you this. Apparently while Engr. Fernandez was supervising his crew for their routine inspection of a drilling site, a violent ethnic riot broke out between Orthodox Christians and some Islamic fundamentalists. While he was trying to pacify the warring mob a Molotov bomb suddenly exploded in front of him, seriously injuring him. He was fortunate that some of his crew members promptly rushed him to the hospital where his otherwise fatal condition was stabilized just in the nick of time." Faith's vision turned blurry and she collapsed while Mr. Cooper and Ms. Gutierrez were still talking about some more details.

When she regained her consciousness, she was already in her room being attended to by a puffy-eyed Millicent who prepared a piping hot noodle soup and tea for her, while the visitors were already gone. "Mama, the Americans assured me that papa is doing fine right now. But we will just have to wait until he is ready to take his Manila-bound flight. The lady, Ms. Gutierrez, mentioned that it might take him three more weeks of stay at the hospital there in Arabia. Mr. Cooper left us his direct phone number. Please take some of this warm stuff. We need to be very very strong for this." 
The incident in that faraway desert made Faith and Millicent's daily and weekly routines totally awry. After several frantic calls to Arnold's company's Manila base, Faith received an instruction from Mr. Cooper that their company would be the one to take charge of transporting her husband from the Centennial Airport to their suburban home. On the fourth week after the accident, Fred, Peter and Juliana accompanied the mother and daughter in their home to welcome Arnold. When the doorbell chimed, the group rushed outside and was greeted by the Filipino driver. From where they were standing they could see two paramedics lowering down from a white van into a chrome plated wheelchair a pathetic figure of an amputee with a horribly disfigured face. Fred grabbed the chair's handles and steered it towards the main entrance of the house. Arnold feebly mumbled: "This is my saddest, and also the last, homecoming. But it is a homecoming, nonetheless." The Filipino driver proceeded to unload his meager belongings, four boxes, a traveling bag, and a leather case containing his acoustic guitar, while the two paramedics were approached by Juliana for their patient's medical records.

Faith's heart was crushed as she watched their daughter weakly kneeling down in front of the mangled form of the man whom she loved so much and who toiled so hard in a scorching land just for them to lead a comfortable life. She could hear Millicent talking to him: "Papa, we should be happy that you made it through that accident. I will take good care of you. I love you very much." His smooth dark skin was now permanently scarred by fire, shards and stitches. What remained of his healthy long hair are patches of wiry stubbles. His once muscular and rugged stance slumped helplessly in the wheelchair. Only the faint gleam of a will to survive in his eyes was there to remind Faith that he was the same bohemian artist and reckless student leader whom she agreed to be steady with some years ago underneath a fire tree bough in their bucolic university garden.

Her most cherished dreams about their future had just overturned into a harrowing nightmare, as it dawned upon her that the long awaited time had finally come when their family will be physically whole once again, when they could have their breakfast and dinner together day after day, when there would be no more poignant goodbyes at the Centennial Airport, and when she and Arnold would be pursuing their highly ideological advocacies hand in hand. All of these were dumped on her feet with a painful and unexpected twist. But Faith knew that with all the love and hardships they had shared, they could pull through this earth shattering moment of their lives.

Department of Filipino, De La Salle University-Manila, Philippines 